\title{
MODELS OF GOVERNANCE - A VIABLE SYSTEMS PERSPECTIVE
}

\author{
John Davies \\ School of Management, Victoria University of Wellington, PO Box 600, Wellington, New Zealand, \\ Tel: +64-4-463 5382, Fax: +64-4-463 5253, email: john.davies@vuw.ac.nz
}

\begin{abstract}
This paper suggests a framework for examining governance issues spanning the corporate, public and nonprofit sectors that draws on existing frames-in-use, and that reflects the systemic communality apparent within varied attempts to describe and effect change in governance. The paper surveys alternative conceptualisations of governance that have surfaced in the academic and practitioner literature and draws attention to the cybernetic and systemic features of diverse views of governance. Beer's viable systems framework is used to reinterpret alternative views of governance and to suggest a means of diagnosing the completeness/coherence of governance systems.
\end{abstract}

Keywords: governance, governance systems, corporate governance, viability, viable systems

\section{INTRODUCTION}

This paper begins by outlining a seeming diversity of views and conceptions of governance. Then, following a brief resumé of Beer's work, these views will be examined and reinterpreted using Beer's systems framework. The paper will conclude with some observations on the usefulness of Beer's framework in understanding the systemic roles and functions required of governance in determining the viability of organisations.

Issues in Governance

Jessop (1998, p 29) claims that the notion of 'governance' has only recently entered what he terms the 'anglophone social science lexicorn'. Yet even so, he states that in its short life, its usage has been eclectic, diverse and 'pre-theoretical'. Kay et al. (1995, p 84) comment similarly that whilst issues of governance may have existed for as long as there have been social institutions, the now common-or-garden term 'corporate governance' did not emerge until the seventies.

Common conceptions of governance connote not only government and governing, but also the activities of governing boards and bodies, the terms often being used interchangeably (Stoker, 1998, p 17). The opinion of Maw et al. (1994, p 1), based on their practitioner experiences, that '(c)orporate governance is a topic recently conceived, as yet ill-defined, and consequently blurred at the edges', is somewhat in keeping with these and many other views, and with empirical findings that describe corporate boards as 'complex, dynamic human systems charged with an ill-structured set of responsibilities' (Demb et al., 1992), findings which have been endorsed by Cadbury (1999, p 15), and which have a counterpart in the nonprofit sector (Middleton, 1987, $\mathrm{p}$ 141). The implicit criticisms of the lack of a common view, or the lack of a commonly accepted view, and perhaps the lack of rigour in defining governance, have led to different research agendas amongst academics and practitioners.

Since the seventies, interest in corporate governance has been catalysed by considerable media attention given to poor company performance, corporate failure, inappropriate accounting/audit practices, excessive remuneration packages for senior managers and executive directors, insider trading, pension fund mismanagement etc. But, as implied by Kay et al. (1995: 84), such events are not just recent phenomena, and much of the increased scrutiny can be attributed to the advent of harsher economic conditions that have drawn to the surface these manifestations of underlying corporate frailty, weaknesses or excesses.

Growing interest in governance can also be attributed to enhanced awareness by those organisations that operate in an international context, of the different governance practices that exist in an increasingly global corporate sector operating in global markets (Witherell, 1999, p 78; Lannoo, 1999, p 270; Cadbury, 1999, p 13). Additionally, the extent to which governance issues pervade society is exemplified by the behaviour of organisations in the voluntary or non-profit sector, and by their perceptions of the role and importance of governance. Many leading sports bodies have restructured their govemance processes voluntarily in recognition of a need to bring about greater organisational effectiveness (Davies, 1997), accepting the notion that performance is predicated on effective governance (Schlefer, quoted in Byrne, 1998, p 82-85). Others have engaged in reforms of the governance and management structures, for example, the Football Association in England, to effect change to the balance of stakeholder representation and stakeholder interests, and to limit any potential abuse of executive power. At the European level, the erstwhile success of UEFA in developing its marketing, commercial, and financial strengths, followed by the collapse of its marketing agency in 2001, has focused attention on its governance processes, particularly the relationship between governors, executive management and their agents. Indeed, the changes that are taking place in the world of sport reflect a climate that mirrors the movement for reform of corporate governance described by Tricker (1984), Cadbury (1992). In an interesting comparison to governance issues arising in sport, Hampel $(1998, \mathrm{p} 9)$ contrasts the perspective of his report to that of earlier work (Cadbury, 1992; Greenbury, 1995). He suggests that whilst their approach and 
guidelines 'concentrated largely on the prevention of abuse', responding to 'things which were perceived to have gone wrong', his work was equally concerned with the articulation of principles of corporate governance that would make a positive contribution to organisational life. The collective result now appears as the combined UK code on corporate governance (Parkinson et al., 1999, p 101; Lannoo, 1999, p 283). Similar initiatives have taken place worldwide.

\section{GOVERNANCE - AS ACTIVITIES, FUNCTIONS, NETWORKS AND SYSTEMS}

Maw et al. (1994, p 3) have conceptualised corporate governance as a complex of relationships - involving duties and obligations - between the board, its shareholders, financiers, customers, employees, auditors and regulators. Based primarily on substantial practitioner experience, they too, have developed a prescriptive framework - a suggested code of practice for boards, favouring compliance - to guide boards in meeting their 'a priori' duties, and legal obligations. However, somewhat differently, Demb et al (1992) have sought empirically to discover how board roles relate dynamically to the internal and extemal forces impinging on the organisation. They take a systems view and see boards as part of a wider system of governance, beyond duties and obligations. Demb et al. (1992) conceptualise a governance system wherein a board, as a sub-system, has an integral, interdependent role interacting with, and being influenced by three other sub-systems - the wider regulatory system, the system of ownership, and the societal system. They argue that '(c)orporate governance is the process by which corporations are made sensitive to the rights and wishes of their stakeholders', a stance disputed by Argenti (1997), who acknowledges shareholders, as owners, to be the only legitimate stakeholders. We note that Parkinson et al. (1999, p 101) suggest that the three major reports on corporate governance in the UK (Cadbury, Greenbury and Hampel) were predicated on the shared assumption that 'governance is understood to be about the relationship between shareholders (ie the owners) and managers'. Such debates that have taken place in the literature often reflect different perspectives of the nature of governance and of what constitutes an appropriate balance of these interests and activities.

Others have offered similar notions to Demb et al. (1992), outlining 'governance frameworks' or 'systems of governance' within which organisations operate. Cadbury $(1998, \mathrm{p} 2)$ describes a framework structured by interacting forces: by the force of law impacting upon organisations; by the regulatory forces of, for example, the Stock Exchange; by shareholder meetings and by the force of public opinion. Allison (1998, p 29) has similarly commented that 'the system of contemporary world governance in sport' is also one of complex interdependence - between intermational and national governing bodies, international law and the courts, the media, commerce and business, the fans and the public etc. Worthy et al. (1983) offer yet a similar view that governance is 'concerned largely, though ... not exclusively with relating the corporation to the institutional environment within which it functions.' Issues of governance for them include 'the legitimacy of corporate power, corporate accountability, to whom and for what the corporation is responsible, and by what standards it shall be governed, and by whom'.

The implication is that discussing governance and governing boards in terms of structural elements - size, committees, roles, meeting frequency, board fees, chairman and CEO relations - may be necessary, but not sufficient to build understanding of the governance processes that facilitate effective functioning (Demb et al., 1992; Cadbury, 1998; Charkham, 1994; Pettigrew et al., 1995). Indeed, as suggested by Charkham (1994, p 6), understanding a system of governance 'means studying both its structure and dynamics', that is, not just the legal framework but also personal relationships and patterns of behaviour. In addition, Demb et al. (1992) contend that effective board performance is linked to an appropriate understanding of the tensions, or paradoxes, that would otherwise 'destabilize' boards.

The desire to promote effective corporate governance and to effect appropriate board member behaviour has been manifest in different prescriptive approaches. Whilst Maw et al. 's code of practice addresses perceived structural requirements, Carver's approach $(1999,1997)$ is intended to guide a board's debate so that it embraces values in the consideration of necessary governance functions. Maw et al. 's code relates to the composition of the board, specifying a minimum number of non-executive directors, and appointment criteria. It addresses the functioning of the board, specifying responsibilities and matters 'reserved' for board consideration; accountability: directors' responsibilities, disclosure and compliance requirements, sanctions; and the use of independent non-executive board committees for audit, remuneration and director nomination purposes. Carver goes beyond Maw et al.'s embrace of duties and obligations, and seeks to engender debate on values about ends, results, impacts, goals etc, and to whom, as constituents, they relate. He also focuses attention on the values that can be attributed to means - that they are employed in a prudent and ethical way; and on values implicit in the board-executive relationship - affecting the delegation of authority and power, the CEO's role, performance assessment etc.

Whilst some of these prescriptions are likely to have relevance for organisations in both the corporate and the non-corporate sector (Charkham et al:: 1999, p 242-243), there is minimal guidance for those who seek to determine the appropriateness of any prescription. It is this latter inadequacy of descriptive and prescriptive 
frameworks that needs to be addressed. In the final sections, we seek to employ a Beer's viable systems framework to develop perspectives and insights about governance that more directly address the nature of effective governance functioning, and the adequacy of prescriptions.

\section{BEER'S VIABLE SYSTEMS FRAMEWORK}

Beer's approach $(1979,1981,1985)$ to issues of organisational design and effectiveness, just like Cadbury's approach to governance $(1992,1998$; also quoted in Demb et al., 1992, p vii-viii) is not pre-occupied with structure. Neither is the approach pre-occupied with the organisational typologies often used to reflect structure, or the configurations that are often embodied in organisational charts.

Instead, Beer focuses on the systemic functions that enhance organisational viability, and which provide a basis for adaptive learning about what are effective organisational behaviours and goals in a climate of complexity and change (Davies, 1999). Beer's research $(1979,1981,1985)$ has demonstrated that certain systemic features or functions are necessary to any system's viability or survival. To be viable in Beer's terms, that is, to survive and be effective, an organisation must be able to manage uncertainty and complexity by achieving requisite variety of response. It can develop requisite variety either by creating increased variety in its own systemic behaviour and functioning, or by acting as if to reduce the environmental variety to which it would otherwise be exposed. Knowledge of these systemic functions can therefore be used to analyse the systemic strengths and weaknesses in existing organisations, and/or to, guide the design of organisations to provide required systemic features. Beer's cybernetic framework for analysing organisational systems is known as the Viable Systems Model (VSM).

The use of cybernetic science to underpin the design of self-regulating, adaptive technical systems that can maintain required outputs, and work within established norms, is well known and predates Beer's attempts to extend its use to organisational systems (Francois, 1999; Shenhav, 1995). However, Beer's conceptualisation of cybernetics as 'the science of effective organisation - the science of communication and control, in the animal and the machine', extends the applicability of cybernetics beyond natural and technical systems. Indeed, in doing so, he emphasises the importance of communication as part of organisational systems design - building communication channels, generating information flows and installing information feedback mechanisms - to enhance leaming and adaptive response, that is, to develop requisite variety in action.

The Viable System Model

Beer conceptualises all viable systems as a network of communication channels bonding five complementary sub-systems. The sub-systems, whose effective functioning and communication links are necessary to any system's viability, comprise - an operational system, S1, of autonomous operational units that act out the very identity and purpose of the overall system, and a meta-system comprising four other sub-systemic functions: S2 effecting overall coordination of the autonomous units; S3 - operational planning, monitoring, control and audit functions relating to the autonomous units; S4 - intelligence and strategy development serving the whole organisation's future; and S5 - the creation and promulgation of identity, vision, direction, purpose and mission, throughout the organisation and its wider environment (Brocklesby et al., 1995). All sub-systems are part of the larger system under investigation, which is defined as the System-in-Focus (SIF). In terms of systems logic, no one sub-system is considered to be more important than another in contributing to the viability of the SIF. However, it will be S1's activities that directly serve the organisation's purpose; and it will be the meta-system's function to provide the organisational climate, the direction, resources and support for S1 to best manage in a changing complex environment, and for the $S 1$ units to become viable sub-systems themselves at a lower level of recursion or embeddedness. The SIF may, itself, be part of, or embedded within a larger organisation or system (Davies, 1999).

In contemplating the use of Beer's VSM to examine aspects and models of governance, we take the view of Rosenau (1992, p 3) who states that 'to presume the presence of governance ... is to conceive of functions that have to be performed in any viable human system'. Interestingly, and without reference to Beer, those functions are listed as setting goals, developing strategies and policies, procuring resources necessary for 'preservation and well-being', preventing conflict among its members or factions from tearing it apart etc, and more generally, as a measure of effective functioning, coping with environmental uncertainty and external challenges. 'Whether the systems are local or global in scope, those functional needs are ever present if a system is to persist intact through time.'

\section{OTHER MODELS OF GOVERNANCE}

This section outlines various models of governance which have been identified as exhibiting cybernetic features and functions, and uses Beer's VSM to examine the systemic qualities, completeness and coherence of the different models. First, we look at the models of Young (1996), who focuses on information and feedback mechanisms, and Jessop (1998) and Rosenau (1992) who explicitly refer to systemic functions of governance. 
Then we use the Beer's framework as an interpretive filter to identify the systemic qualities of models of governance proposed by Carver (1997), Charkham (1997), Kay (1995), Senge (1999).

Young (1996, p 15-17), has proposed a feedback model of governance. He has made explicit reference to the cybemetic concepts of positive and negative feedback in describing the function of governance as being 'to keep an organisation on course by detecting where it is going and providing information that will allow necessary corrections to that course.' Young asserts that govemance is not just about boards, but can be regarded as 'a cluster of mechanisms that measure an organisation's performance and feed it back.' Young suggests that his model thus accommodates and complements the notions of Middleton (1987, $p$ 143) relating to the boundaryspanning and control' role of boards in the necessary and purposeful transfer/feedback of external information to managers.

He conceives of board roles as reflecting and harnessing the nature of feedback. For example, with negative feedback mechanisms, one measures the difference between desired and actual performance, in order to move performance closer to the target level, a process of homeostasis, that is, self-adjusting stability. Young thus interprets the work of a 'negative governor' as being to ensure that the organisation stays on course and focussed on achieving its mission. Then, since positive feedback mechanisms work to reinforce movement away from pre-determined levels, creating either spiralling success or ever-decreasing performance levels, he describes the work of a 'positive governor' as being to provide the condition and support for growth and innovation.

Young understands the importance of feedback and information flows, but his conceptualisation does not differentiate between external feedback along horizontal communication channels and internal feedback via vertical communication channels, in the way that Beer's framework does. This point may be illustrated with an example of feedback mechanisms operating within a system comprising an international association of member groups. If the international association is performing inappropriately or poorly, then as is now the case with FIFA, it is possible for the continental confederations, acting as de facto S1 operational units, to vocalise their concerns 'upwards' along vertical communication channels to the FIFA meta-system, perhaps demanding changes. This can be described as an example of 'bottom-up' accountability. On the other hand, FIFA in seeking to make its member organisations accountable for specific activities and targets, may require formal reporting an example, in Young's terms, of top-to-bottom accountability. Both sets of information can be conceptualised as flow along vertical communication channels within the organisational system, with the confederations being S1 viable systems 'nested' within the system that is FIFA. However, boundary-scanning activities can be described as an example of horizontal information exchange, with horizontal communication channels providing a conduit between the system and its various environments.

Young's model implicitly accepts governance responsibilities as including systemic functions such as 'steering' and the setting of strategic direction (S5); the maintenance of an intelligence function, the development of strategy and a capacity for self-assessment (S4); and the resourcing of activities together with the development of accountability and control mechanisms to keep things on course (S3). His explicit precondition is, of course, the development of information networks to build a capacity for learning, adaptability and requisite response. So, Young's model of governance, whilst nominally emphasising feedback, can be stated to exhibit many of the meta-systemic qualities required of viable organisations.

Jessop (1998, p 29) conceptualises governance as referring 'to any mode of coordination of interdependent activities', such as that created through the development of a planned formal organisational hierarchy, a selforganising 'heterarchy', or even the anarchy of exchange that constitutes free markets. Jessop sees heterarchy as being as relevant at the level of self-organising inter-personal networks as it may be in the self-organising of agencies, institutions or systems 'which are operationally autonomous from one another yet structurally coupled due to their mutual interdependence.'

Jessop (1998, p 30) contrasts the self-organisation of inter-organisational relations with the notion of 'de-centred, context-mediated inter-systemic steering' as described by Glagow and Willke (1987). In the latter scenario, Jessop suggests that whilst the often complex operational logic of a differentiated sub-system may prevent effective control of the wider system's development from the outside, it does not prevent some 'context specific' steering. He offers a view that inter-systemic 'noise reduction' can be achieved through appropriate direct communication involving negotiation, cooperation in shared projects, and what he terms 'negative coordination' activities to prevent mutually undesirable outcomes. The latter notion equates with Beer's anti-oscillatory behaviour.

Whereas Young seemingly emphasises feedback and control, Jessop emphasises coordination. However, Jessop's notion of 'coordination' can be interpreted as contributing to various systemic functions in diverse ways at different levels of recursion relating to the system-in-focus (SIF). In particular, his notion of inter-systemic 'noise reduction' can be regarded as equivalent to $\mathrm{S} 5$ building of shared values and identity for the organisational system that comes together with a common purpose of conducting mutually beneficial business. On the other hand, employing a code of practice to prevent undesirable outcomes emanating from S1 units acting with designed levels of autonomy, would constitute the coordination as being an S2 function for the SIF. 
Although Jessop does not deny the importance of information, it does not hold as central a position in his model as it does for Young. Nevertheless, Jessop's use of the term 'context-mediated steering' does imply building an S5 strategic flexibility or responsiveness to S4 knowledge of environmental change. Indeed, in acknowledging the inevitable incompleteness of attempts at coordination, Jessop (1998, p 43) implicitly surfaces the cybernetic necessities required of any viable system, which are to engage in double-loop learning (Beer, 1959) and to build through this self-reflexive capacity for learning, an adaptability and requisite variety to respond to internal and external change.

In enunciating his 'principles' of good corporate governance, Charkham has stated that management must have freedom and autonomy to drive the enterprise forward, of course - 'exercised within a framework of effective accountability' (Charkham, 1994, p 4; Governor, 1992, p 211). Indeed, he has stated that 'the main point of a good (governance) system is to give power to those best able to use it' (Charkham, 1997, p 3). His view is that a system of corporate governance should be 'concerned with checks and balances on the exercise of power, and with its peaceful transfer'. Indeed, Charkham has been forthright in asserting that the success of a corporate governance system is dependent upon 'its ability to reconcile entrepreneurial freedom with effective accountability', or as Beer frames it, to effect an appropriate balance of S1 autonomy and meta-system control. Although working predominantly in the corporate sector, Charkham (1993, p 391), claims that these principles of governance have relevance in many other spheres of activity - economic, political, sporting etc.

Senge (1999, p 10-11) offers a different notion of what constitutes power or control, commenting that 'the source of legitimate power' in an organization is its guiding ideas, values and ideals, its mission, purpose and reason for being. He asserts the need for an organisation or any human community to express its aspirations and to articulate its identity to provide a basis for evaluating whether strategic and operational decisions reflect vision and mission oriented behaviour. In doing so, he is expressing the need for S5 functionality. He implies consequent impact on authority/control mechanisms and on operational activities, suggesting for example, the need for less formal approaches to say, coordination and control, as identity and values pervade the organisational system and its nested sub-systems, guiding behaviour and choice. Such views fit within Beer's framework, and provide a complementary view to the notions of authority and power expressed by Charkham.

In contrast with the prior frameworks of governance that give explicit emphasis to a subset of systemic features, Rosenau's model (1992: 3) can be considered more comprehensive. He conceives of governance as equating with the broad provision of necessary meta-systemic functioning relating to setting objectives (S5), developing policy options (S4) and policy guidelines (S3), resource acquisition (S3), anti-oscillatory coordination (S2) etc. Other writers offer models or views of governance that bear surface resemblance to, but are not founded on or legitimised by viable systems thinking. For example, without being specific about meta-system functions, Chelladurai (1987) has suggested taking a 'Parsonian' perspective on organisational design, and on board functioning. In relation to the design of amateur sports organisations, he has advocated the separation of the board as an 'institutional' sub-system from the managerial and technical sub-systems. However, any comparison between the contribution of the board to Beer's meta-system and the role of the board in Chelladurai's 'institutional' sub-systems is limited by the ambiguity and lack of clarity about the conceptual and functional make-up of Chelladurai's sub-systems. We may conclude that any resemblance of the 'institutional' sub-system to Beer's meta-system is perhaps coincidental rather than based on cybernetic considerations.

However, Carver's values-led-policy-driven governance framework (1997) can be considered to be as comprehensive as Rosenau's, and to have notable systemic coherence. Carver's prescriptions relate predominantly to S5/S4 meta-systemic functions, and cohere with Beer's notions of the systemic functions that engender viability and the long-term sustainability of organisations. In particular, Carver promotes governing board S5 behaviour that builds identity by facilitating diversity; that is relationship oriented, identifying and describing constituencies and accountabilities; that is values driven, explicitly addressing fundamental values; that is visionary; that is proactive, leading and creating rather than approving, reviewing and monitoring etc. Similarly, he would attempt to strengthen S4 functionality by endorsing forward thinking, taking the long term view; by developing an external focus, building responsiveness; by valuing intelligence; by being self-aware and how it engages in self-monitoring; by how it represents the 'ownership', and how it seeks an understanding of its systemic role on any matter. Carver's awareness of the need to seek the right balance between autonomy and control reflects the systemic balancing act between S3 and S4, and then between S3/S4 and S1; and his call for decisions to be outcome driven, weighing decisions against purpose, would require and lead to enhanced S2/S3 functionality (Carver, 1997, p 32-33; 1999, p 1-10).

In many ways, Kay et al.'s trusteeship model of corporate governance (1995, p 90-91) shares similarities with Carver in its value-laden expression of governance responsibilities. Their conception of governance requirements is in line with the views of Young (1996, p 15-17), Jessop (1998, p 29), and Demb et al. (1992), in seeking 'to balance the conflicting interests of current stakeholders ... to weigh the interests of present and future stakeholders'. In Kay et al.'s view, trusteeship responsibilities require effective governance 'to sustain the corporation's assets', including such assets as its identity, reputation, the skills of its employees, and the favourable expectations of customers and suppliers etc. Effective governance, in Kay et al.'s view, can thus be 
interpreted as being primarily dependent upon S5 functioning involving the building and sustenance of appropriate identity and values related to reputation, the values placed upon relationships with employees, suppliers, customers etc. As such, they concur with Demb et al. (1992) in a concern 'to balance the intimacy of operational involvement with the detachment presumed to be required for objective strategic review and analysis etc'.

\section{DISCUSSION AND SUMMARY}

Charkham (1994: 248) has remarked how difficult it is to be objective with the familiar, and that to shed light on governance may require the examination of alternative governance systems, and the development of alternative perspectives. This paper has outlined a variety of views of governance practices, processes and systems, and has demonstrated the value of a systemic perspective and of Beer's framework in attempting an evaluation of alternative models of governance.

As Espejo et al. (1989, p 445) propose, if we accept the notion of a 'model-as-convention', rather than as a description of reality, then, at the very least, we can accept Beer's model as providing a context which provides 'a way of talking about something in a manner that is understandable and useful, that is, as a communication vehicle'. Indeed, Beer's organising framework, the VSM, 'provides a language in which to identify key features of a complex reality', and can help to pose significant questions about that reality (Stoker, 1998, p 1). As such, Beer's model can act in the form of a sensitising framework - as a way of seeing and thinking which alert the analyst to alternative ways of understanding (Thomas, 1993, p 210). Just as Carver (1997, p xvi) claims that his values-based policy model enables board members to see their role in a new light, so, too can Beer's framework provide an alternative perspective on the design of governance relations.

Beer's conceptualisation of viability in organisations is based on cybernetic and systems concepts and a consideration of the systemic functions that contribute to systems viability. Beer would contend that organs, instruments, activities and processes of governance need to be effective in the sense that they establish or contribute to the maintenance of systemic identity and purpose(s) which have coherence, and which are projected, shared and accepted within and without the organisation by its internal and external constituents. That identity is obviously linked to the organisation's purpose, its raison d'être, and together, they can provide a guiding beacon and logic that cultivate the values and ethics that underpin ends-oriented and mission-oriented behaviour.

Effective organs of governance must balance the competing attentions of multiple constituents, and of long and short-term objectives. In keeping with fundamental purpose and values, the processes of governance must decide on strategic direction and goals for the organisation, and be capable of assessing the performance of senior management in operationalising those goals. Those involved in governance processes, for example, a governing board, must also be capable of critical self-reflection, self-monitoring and self-assessment, that is, they must be capable of embracing in concept, a 'model' of the organisation - its purpose, identity, structure, functioning etc.

These are primarily S5 and S4 functions within Beer's framework. Beer's approach, however, requires recognition of the need for quick response to environmental change, the need for adaptability - or to use Demb et al.'s terms (1992, p 195), 'the imperative of adaptability'. It implies autonomy to act, within Charkham's framework of controls and accountabilities, and within the 'tight-loose' framework of Peters and Waterman (1980), but which in Beer's terms and in Carver's terms means working within a framework of S2 policy guidelines and 'controls', whose development is a necessary S3 systemic function, reflecting S5 identity and values.

In reflecting on Beer's model of viable organisations, we note the role and functions of govemance as being a sub-set of meta-system roles and functions: creating identity, building shared values and purpose, setting direction, steering; providing resources and delegating authority for managerial and operational staff to act with autonomy and appropriate responsiveness in changing environments. However, many of those involved in governance roles fulfil other systemic functions within organisations. For example, in many voluntary organisations, at local, regional or national governing body level, those elected or appointed to take on S5 stewardship of the organisation, to guide its future direction and activities, are often the volunteers who undertake S1 operational activities. They may also engage in S3 operational planning and budgeting activities, and in S4 strategy development activities.

The potential for systemic role conflict to exist is apparent. Unless those who are charged with S4 governance functions are able to conceptualise the organisation's being, and to view its activities in a holistic sense, that is, in systemic terms, then it is possible that in failing to recognise the various systemic functions and roles that exist, they will, as volunteers, engage in multiple systemic activities, creating role overload, role overlap and role conflict. Indeed, one common systemic ailment arises when, with the best of intent, the S5 governors necessarily engage in $\mathrm{S} 1$ activities, but in doing so denude $\mathrm{S} 1$ staff of their autonomy, undermining initiative etc. 
Additionally, when board members, governors or trustees are elected from (or possibly to serve) particular constituencies, difficulties may arise in building common identity, purpose and values for the organisation. The systemic dysfunction most likely to be caused by parochialism amongst say, governors can then be described as that of S5 dysfunction - lack of identity, lack of common purpose, lack of shared values etc.

We conclude that understanding governance requires a holistic approach. Conceptualising governance and board activities in terms of Beer's systemic roles and functions not only delivers insights about the design of governance, but also contributes understanding to common issues of role overload and role conflict that arise among governing board members, and which can impact adversely on board/staff relationships. Moreover, the VSM provides clarity in disentangling the various views about what constitutes governance. Indeed, using the VSM as an interpretive framework suggests that there is evidence that concepts and notions that are cybernetic in nature, and which underpin viability, are incorporated within extant models of governance, but mostly in piecemeal fashion. Such models can be regarded as incomplete when set alongside Beer's model of viability and systemic functioning.

However, pursuit of the Beerian ideal may not be straightforward. Beer's emphasis on systemic functioning supports the views of Boyd (1995, p 301) and Demb et al. (1992, p 182) that mimetic behaviour, copying the structure of another board, or following blanket prescription, will unlikely work any better than for, say, a production line subject to different demand patterns. As Cadbury (1999, p 18) has stated, whereas market forces can be expected 'to bring about a convergence of governance standards and processes', he would 'neither expect nor see the need for a convergence of governance structures'. Effective governance is dependent on an understanding of required systemic functioning and other systemic requirements, rather than structural or procedural mimicry.

\section{REFERENCES}

Allison, L. (1998) "The government and govemance of sport", Politics Review, September, pp 28-30.

Argenti, J. (1997) "Stakeholders: the Case Against", Long Range Planning, 30(3), pp. 442-445.

Ashburner, I. (1997) "Corporate governance in the public sector: The case of the NHS", in Keasey, K.,

Thompson, S. \& Wright, M. (eds.) Corporate Governance: Economic and Financial Issues, Oxford: OUP, Ch 13, pp. 279-297.

Beer, S. (1985) Diagnosing the System for Organisation, Chichester: Wiley.

Beer, S. (1981) Brain of the Firm (2nd Edn), Chichester: Wiley.

Beer, S. (1979) The Heart of the Enterprise, Chichester: Wiley.

Beer, S. (1959) Cybernetics and Management, London: English Universities Press.

Blair, M.M. (1995) Ownership and Control: rethinking Corporate governance for the Twenty-first Century, Washington DC: Brookings Institute.

Boyd, B. K. (1990) "Corporate linkages and organizational environment: A test of the resource dependence model", Strategic Management Journal, 11(6), pp 419-430.

Boyd, B. K. (1995) "CEO Duality and Firm Performance: A contingency Model" Strategic Management Journal, 16, pp 301-312.

Brocklesby, J., Cummings, S. \& Davies, J. (1995) "Demystifying the Viable System Model as a Tool for Organisational Analysis", Asia Pacific Journal of Operational Research, 25(1), pp 65-86.

Byrne, JA. (1996a) "The National Association of Corporate Directors' new guidelines won't tolerate inattentive, passive, uninformed board members", Business Week, No. 3503, November 25, pp. 100-102

Byrne, JA. (1996b) "Commentary: Putting Your Money Where Your Mouth Is", Business Week, No. 3503, November 25, p 106.

Cadbury, Sir A. (1999) "What are the Trends in Corporate Governance? How will they affect your Company?", Long Range Planning, 32(1), pp 12-19.

Cadbury, Sir A. (1998) "The Future for Corporate Governance: The Rules of the Game", Journal of General Management, 24(1), Autumn, pp 1-14.

Cadbury, Sir A. (1992) Report of the Committee on the Financial Aspects of Corporate Governance (1993). London: Gee Publishing - aka The Cadbury Report

Campbell, A. (1997) "Stakeholders: the Case in Favour", Long Range Planning, 30(3), pp 446-449.

Carver, J. (1997) "Boards that make a difference: A new design for leadership in nonprofit and voluntary organizations", $2^{\text {nd }}$ Ed., San Francisco: Jossey-Bass.

Carver, J. (1999) The unique double servant-leadership role of the board chairperson. The Reprint File: $\mathrm{http}: / / / \mathrm{www}$.carvergovernance.com/tr.htm.

Charkham, J. (1993) "The Bank and corporate governance: past, present and future", Bank of England Quarterly

Bulletin, August, pp 388-392.

Charkham, J. (1994) Keeping good company: a study of corporate governance in five countries, Oxford: OUP. 
Charkham, J. \& Simpson, A. (1999) Fair Shares: The Future of Shareholder power and responsibility, Oxford: OUP

Chelladurai, C. (1987) "The design of sport governing bodies: A Parsonian perspective", in Slack, T. \& Hinings, C. R. (eds) The Organization and Administration of Sport, London Ontario: Sports Dynamics.

Collins (1994) Collins English Dictionary. $3^{\text {rd }}$ Edition, Glasgow: Harper Collins Publisher.

Comforth, C. \& Edwards, C. (1998) Good Governance: Developing Effective Board-Management Relations in Public and Voluntary Organisations. London: CIMA.

Davies, J. (1997) "Designing Sustainable Sporting Organisations:, in Stowell, F.A., Ison, R.L., Armson, R., Holloway, J., Jackson, S., \& McRobb, S. (eds) Systems for Sustainability - People, Organisations and Environments, London: Plenum, pp 191-197.

Davies, J. (1999) "The Effective Organisation of National Sports Bodies in NZ - a Systems Perspective", in Trenberth, L. \& Collins, C. (eds) Sports Management in New Zealand, Palmerston North: Dunmore Press, pp 109-131.

Demb, A \& Neubauer, F-F. (1992) The Corporate Board: Confronting the Paradoxes. Oxford: OUP.

Espejo, R. \& Harnden R. (1989) "The VSM: An Ongoing Converstion", in Espejo R. \& Harnden, R. (Eds), The VSM: Interpretations and Applications of Stafford Beer's VSM, Chichester: Wiley, pp. 445.

François, CO. (1999) "Systems and Cybernetics in a Historical Perspective", Systems Research and Behavioural Science, 16(3), pp 203-220.

Glagow, M. \& Willke, H. (1987) Dezentrale Gesellschaftssteuerung: probleme der Integration polyzentristischer Geseeschaft. Pfaffenweiler: Centaurus-Verlagsgesellschaft, quoted in Jessop, B. (1998) "The rise of governance and the risks of failure: the case of economic development", International Social Science Journal, 50(155), pp 29-45.

Goold, M. (1996) "The (Limited) Role of the Board", Long Range Planning. 29(4), pp 572-575.

Governor. (1992) "Man bites watchdog", Bank of England Quarterly Bulletin, May, pp 388-392.

Greenbury, Sir R. (1995) "Directors' remuneration: report of the study group", London: Gee Publishing.

Hampel, R. (1998). The Committee on Corporate Governance: Final Report. London: Gee Publishing- aka The Hampel Report.

Jessop, B. (1998) "The rise of governance and the risks of failure: the case of economic development", International Social Science Journal, 50(155), pp 29-45.

Kay, J. \& Silbertson, A. (1995) "Corporate Governance", National Institute Economic Review August 95, pp 84-97.

Lannoo, K. (1999) "A European Perspective on Corporate Governance", Journal of Common Market Studies, 37(2), pp 269-294.

Maw, N.G., Lord Lane of Horsell, Craig-Cooper, Sir M. (1994) Maw on Corporate Governance, Aldershot: Dartmouth Publishers.

Middleton, M. (1987) "Nonprofit Boards of Directors: beyond the Governance Function", in Powell, W.W. (eds) The Nonprofit sector: A research handbook, New Haven \& London: Yale University Press, pp 141153.

Parkinson, J. \& Kelly, G. (1999) "The Combined Code on Corporate Governance", Political Quarterly, January 1999, 70(1), pp 101-107.

Peters, T.J. \& Waterman, R.H. (1982) In search of excellence, New York: Harper and Row.

Pettigrew, A. \& McNulty, T. (1995) "Power and Influence in and around the Boardroom", Human Relations. 48(8), pp 845-873.

Pound, J. (1995) "The Promise of the Governed Corporation", Harvard Business Review, March-April 1995, pp 89-98.

Rosenau, J.N. (1992) "Governance, Order and Change in World Politics", in Rosenau, J.N. \& Czempiel, E-O. (eds), Governance without government: Order and Change in World Politics. Cambridge: CUP, pp 1-30.

Schlefer, R.M., quoted in Byme, J. (1996c) "The Best and Worst Boards: our new report Card on Corporate Governance", Business Week, No. 3503, November 25, pp 82-85.

Shenhav, Y. (1995) "From chaos to systems: the engineering foundations of organization theory 1879-1932", Administrative Science Quarterly, 40, pp 557-585.

Senge, PM (1999) "The discipline of innovation", Executive Excellence, June 1999, pp 10-11.

Stoker, G. (1998) "Governance as theory: five propositions", International Social Science Journal, 50(155), pp 17-28.

Thoma, J.E. \& Chalip, L. (1996) Sport Governance in the Global Community. Morgantown, WV: Fitness Inform Tech Inc.

Thomas, A.B. (1993) Controversies in Management, London: Routledge.

Tricker, R.I. (1984) Corporate Governance. Aldershot: Gower.

Witherell (1999) "The OECD and Corporate Governance", Accountancy. June 1999, pp 78-79. 
Worthy, J.C. \& Neuschel, R.P. (1983) Emerging Issues in Corporate Governance, Chicago: Northwestern UP.

Young, D.R., Hollister, R.M., Virginia A Hodgkinson \& Asscociates (eds) (1993) Governing, Leading, and Managing Nonprofit Organisations: New Insights from Research and Practice, San Francisco: JosseyBass.

Young, D.R. (1996) "What does feedback have to do with nonprofit governance?", Nonprofit World, Nov/Dec 1996, pp. 15-17. 
Figure 1 - Views of Governance

\begin{tabular}{|c|c|}
\hline & Views of Governance \\
\hline $\begin{array}{l}\text { Collins ED, 1994: } \\
669\end{array}$ & $\begin{array}{l}\text { 'governance is the action, manner or system of governing; governing is directing, controlling, ruling, } \\
\text { regulating, influencing' } \\
\text { from the Latin, 'gubernare: to steer' }\end{array}$ \\
\hline $\begin{array}{l}\text { Parkinson et al., } \\
\text { 1999: } 101\end{array}$ & $\begin{array}{l}\text { 'governance is understood to be primarily about the relationship between shareholders (viewed } \\
\text { unproblematically as the owners of a company) and managers'. }\end{array}$ \\
\hline Lannoo 1999: 272 & $\begin{array}{l}\text { '(c)orporate governance ... is defined as the organization of the relationship between the owners and } \\
\text { the managers in the control of a corporation.' }\end{array}$ \\
\hline Blair, 1999: 3 & $\begin{array}{l}\text { 'corporate governance ... refers to the whole set of legal, cultural, and institutional arrangements that } \\
\text { determine what public corporations can do, who controls them, how that control is exercised, and } \\
\text { how the risks and returns from those activities they undertake are allocated' }\end{array}$ \\
\hline Blair, 1995: 273 & $\begin{array}{l}\text { 'Governance systems, broadly defined, set the ground nules that determine who has the control rights } \\
\text { under what circumstances, who receives what share of the wealth created, and who bears what } \\
\text { associated risks' }\end{array}$ \\
\hline $\begin{array}{l}\text { Cadbury, 1992: } 15 \text {, } \\
\text { para 2.5; Charkham, } \\
\text { 1994: } 1\end{array}$ & 'Corporate governance is the system by which companies are directed and controlled' \\
\hline Demb et al. , 1992 & $\begin{array}{l}\text { '(c)orporate governance is the process by which corporations are made sensitive to the rights and } \\
\text { wishes of their stakeholders' }\end{array}$ \\
\hline Worthy et al. , 1983 & $\begin{array}{l}\text { 'governance is ... concerned largely, though ... not exclusively with relating the corporation to the } \\
\text { institutional environment within which it functions.' }\end{array}$ \\
\hline Pound, 1995: 90 & $\begin{array}{l}\text { 'corporate governance is not, at its core about power, it is about finding ways to ensure that decisions } \\
\text { are made effectively.' }\end{array}$ \\
\hline Blair, 1995: 273 & $\begin{array}{l}\text { 'Governance systems, broadly defined, set the ground rules that determine who has what control } \\
\text { rights under what circumstances, who receives what share of the wealth created, and who bears what } \\
\text { associated risks'. }\end{array}$ \\
\hline Rosenau, 1992: 3 & $\begin{array}{l}\text { 'to presume the presence of governance ... is to conceive of functions that have to be performed in } \\
\text { any viable human system } \\
\ldots \text { to cope with external challenges, to prevent conflict ..., to procure resources . to frame goals and } \\
\text { policies designed to achieve them' }\end{array}$ \\
\hline Young, 1996: 15-17 & $\begin{array}{l}\text { 'the function of governance is 'to keep an organisation on course by detecting where it is going and } \\
\text { providing information that will allow necessary corrections to that course.' } \\
\text { 'governance is about ... a cluster of mechanisms that measure an organisation's performance and feed } \\
\text { it back.' }\end{array}$ \\
\hline Jessop, 1998: 29 & 'governance can refer to any mode of coordination of interdependent activities' \\
\hline Carver, 1997: 24-25 & $\begin{array}{l}\text { 'excellence in governance begins when boards recognise ... setting goals, ... developing plans ... } \\
\text { depend on values and perspectives ... (these values) ... can be unstated as well explicit' }\end{array}$ \\
\hline Ashburnet, 1997: 280 & $\begin{array}{l}\text { 'Good corporate governance is ... reliant ... upon the (existence) introduction and maintenance of } \\
\text { mechanisms to promote behaviour and performance on the part of the manager, which is in the } \\
\text { interests of the organization's stakeholders.' }\end{array}$ \\
\hline Kay et al., 1995: 84 & $\begin{array}{l}\text { 'key goals of corporate governance: freedom for managers to manage, combined with real } \\
\text { accountability for their performance' }\end{array}$ \\
\hline Charkham, 1994: 3 & $\begin{array}{l}\text { 'the main point of a good system ... corporate governance ... is to give power to those best able to } \\
\text { use it'. } \\
\text { corporate governance is 'concerned with checks and balances on the exercise of power, and with its } \\
\text { peaceful transfer. }\end{array}$ \\
\hline $\begin{array}{l}\text { Charkham, 1994: 4; } \\
\text { Governor, 1992: } 211\end{array}$ & $\begin{array}{l}\text { 'the success of a corporate governance system is ... dependent upon its ability to reconcile } \\
\text { entrepreneurial freedom with effective accountability' } \\
\text { 'management must have freedom and autonomy to drive the enterprise forward, of course - exercised } \\
\text { within a framework of effective accountability' }\end{array}$ \\
\hline Cornforth, 1998: 2 & $\begin{array}{l}\text { 'governance ....... embrace(s) all the functions performed in organisations by the members of their } \\
\text { governing bodies' }\end{array}$ \\
\hline Senge, 1999: 10-11 & 'the comerstone of a truly democratic system of governance is not voting' \\
\hline Allison, 1998: 29 & $\begin{array}{l}\text { 'the system of contemporary world governance in sport' is also one of complex interdependence - } \\
\text { between international and national governing bodies, international law and the courts, the media, } \\
\text { commerce and business, the fans and the public etc.' }\end{array}$ \\
\hline $\begin{array}{l}\text { Thoma et al., 1996: } \\
\text { xiv }\end{array}$ & $\begin{array}{l}\text { 'sport governance ... is particularly concerned with the ways in which sport is organised and } \\
\text { managed }\end{array}$ \\
\hline
\end{tabular}

